\title{
How to Teach Medical Students and Clinicians to Handle Zebras? A Holistic Algorithm to Manage Rare Diseases
}

\section{Tıp Öğrencilerini ve Klinisyenleri Nadir Hastalıklarla Baş Edebilecek Şekilde Nasıl Eğitebiliriz? Nadir Hastalıkların Yönetiminde Bütüncül Bir Yaklaşım}

\author{
Cigdem KANBUROGLU ${ }^{1}$, Mehmet Kenan KANBUROGLU²
}

${ }^{1}$ Recep Tayyip Erdogan University Medical School, Department of Medical Education, Rize, Turkey

${ }^{2}$ Recep Tayyip Erdogan University Medical School, Department of Pediatrics, Rize, Turkey

\begin{abstract}
Rare diseases are common altogether estimated to be 263-446 million people worldwide. Most of the time, they are not included in the curriculum, but medical students, general practitioners, and pediatricians should be educated on how to manage these patients.

We aimed to remark when to suspect rare diseases and define a holistic method to depict how to approach patients suspected of rare diseases and follow them up. We suggested using different methods together and developed an algorithm to provide a rapid and stepwise approach to a possible diagnosis, together with long-term management principles.

Raising awareness of rare diseases among clinicians has paramount importance. However, there is no consensus on how to cover these diverse diseases. We hope the holistic approach will help develop strategies to equip clinicians.
\end{abstract}

Key Words: Congenital Diseases, Genetic Diseases, Primary Immunodeficiencies, Rare Diseases

öz

Nadir hastalıklar hep birlikte dünyada 263-336 milyon insanı etkilemektedir. Çoğu zaman müfredatta yer almamasına karşın tıp fakültesi öğrencilerinin, pratisyenlerin ve çocuk uzmanlarının bu hastalık grubuna nasıl yaklaşmaları gerektiği konusunda eğitilmeleri gerekmektedir.

Biz yazımızda nadir hastalıklardan ne zaman şüphelenmek gerektiği ve şüphelenilen hastalarda ayıııcı tanı ve yaklaşım basamakları ve takipte dikkat edilmesi gereken noktalar konularında bütüncül bir metot tanımladık. Algoritma yardımıla birçok farklı yöntemi birbiriyle iç içe geçmiş, hızlı ve basamaklı bir şekilde kullanarak olası tanıya gidilmesini ve uzun dönem takip prensiplerini önerdik.

Nadir hastalıklar konusunda klinisyenlerin farkındalığının artması hayati önem taşımaktadır. Buna karşın nadir hastalıkların eğitimde nasıl işlenmesi gerektiğiyle ilgili bir fikir birliği bulunmamaktadır. Geliștirdiğimiz bütüncül yaklașımın daha yetkin klinisyenlerin yetiştirilmesinde faydalı olacağını umuyoruz.

Anahtar Kelimeler: Nadir hastalıklar, Konjenital hastalıklar, Genetik hastalıklar, Primer immünyetmezlikler

\section{INTRODUCTION}

During medical training, we used to teach students to think initially of the common diseases in a hierarchical manner while making a differential diagnosis. The phrase "When you hear hoofbeats look for horses, not zebras" is often echoed during the rounds. However, zebras are common in life. Although there is no consensus of the definition, diseases that are less frequent than one in two thousand people are called rare diseases (1). Approximately fifteen to one, amount to 263-446 million people in the world, suffer from one of the rare diseases. Infectious causes, rare cancers, and poisoning are not included in that data; therefore, the real number is expected to be higher (2).
(1)
0000-0002-2525-7676 0000-0001-6859-6689
Conflict of Interest/ Çıkar Çatışması: On behalf of all authors, the corresponding author states that there is no conflict of interest.

How to cite / Atıf yazım şekli : Kanburuglu C ve Kanburogly MK. How to Teach Medical Students and Clinicians to Handle Zebras? A Holistic Algorithm to Manage Rare Diseases. Turkish J Pediatr Dis 2021;15:444-447.
Correspondence Address / Yazışma Adresi:
Received / Geliş tarihi : 16.04.2021 Accepted / Kabul tarihi : 25.05.2021

Online published 13.09.2021

Elektronik Yayın Tarihi

DOI: 10.12956/tchd.917279 


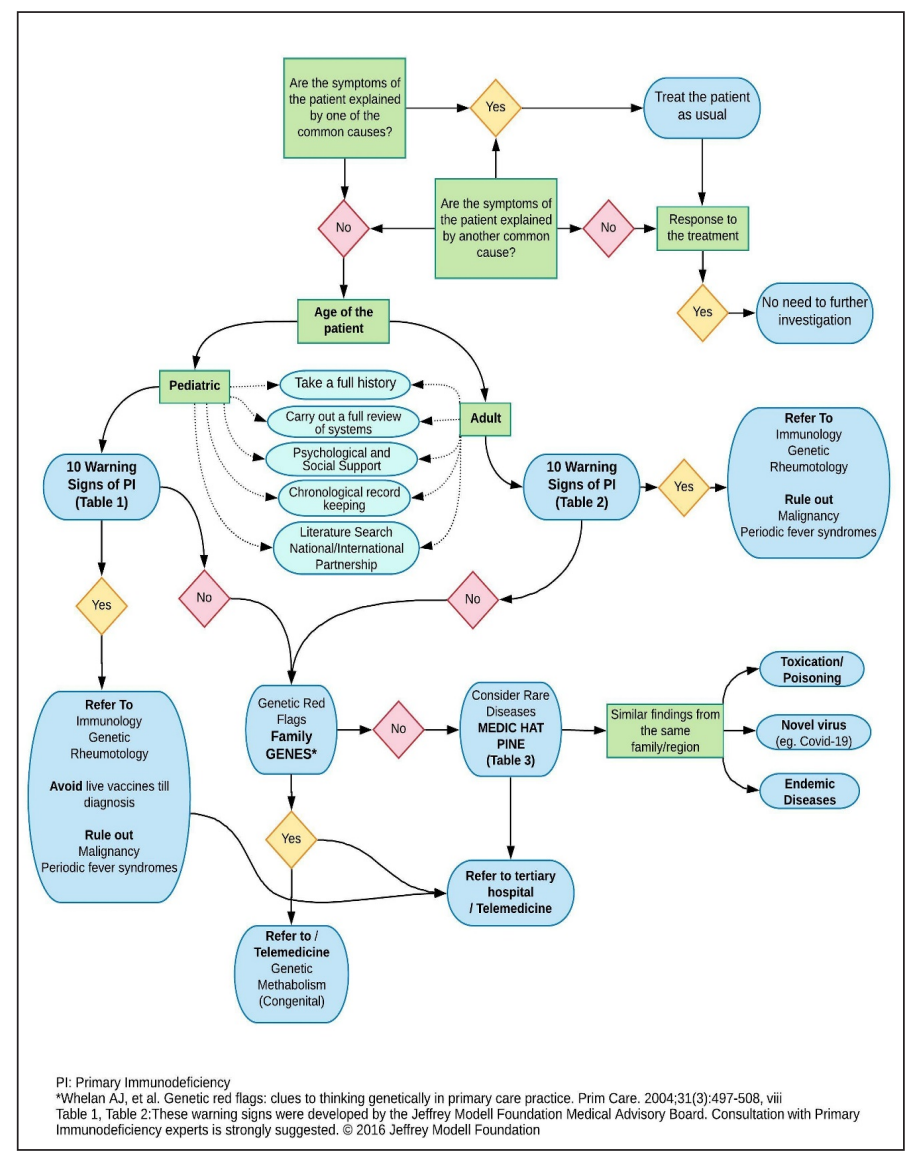

Figure 1: Holistic Algorithm to Manage Rare Diseases

It is impossible to include all rare diseases in medical schools' educational programs, except briefly mentioning a few conditions $(3,4)$. Trying to give a comprehensive approach for each rare disease would be a massive burden as there are approximately ten thousand of them; instead, we should raise awareness and teach how to think and when to think of rare diseases in our daily practice. Edifying a holistic approach is as crucial as making a differential diagnosis, if not more. Considering psychological and social afflictions, addressing to support groups can make a drastic impact on the quality of life of a patient who would probably face diagnostic delays and spend more than five years between 3 to 10 different doctors till the definite diagnosis $(5,6)$.

It is uncertain that who will care for the patient till the diagnosis is made. Besides, patients may be left unattended during the transition from adolescence to adulthood (7). We suggest that the pediatrician, together with the general practitioner (GP) or the family doctor, be responsible for providing support, coordinating between different medical specialties, and keeping solid medical records until and after the diagnosis (8). Almost $80 \%$ of children with a rare disease visit their GP once a year, and most of the families consider their GP as the primary source of information regarding their child's condition (5). Professionalism may come with inattentional blindness; specialists may take
Table I: Ten warning signs of primary immunodeficiencies for children.

1 Four or more ear infections within a year

2 Two or more serious sinus infections within 1 year

3 Two or more months of antibiotics with little effect

4 Two or more pneumonia within a year

5 Failure of an infant to gain weight or grow normally

6 Recurrent, deep skin or organ abscesses

7 Persistent thrush in the mouth or fungal infections on the skin

8 Need for intravenous antibiotics to clear infections

9 Two or more deep-seated infections including septicemia

10 A family history of primary immunodeficiency

These warning signs were developed by the Jeffrey Modell Foundation Medical Advisory Board. Consultation with Primary Immunodeficiency experts is strongly suggested. (C) 2016 Jeffrey Modell Foundation http://info4pi.org/library/educational-materials/10-warning-signs (Access date: 16 April 2020)

Table II: Ten warning signs of primary immunodeficiencies for adults.

1 Two or more ear infections within a year

2 Two or more serious sinus infections within a year; in the absence of allergy

3 One pneumonia per year for more than 1 year

4 Chronic diarrhea with weight loss

5 Recurrent viral infections (colds, herpes, warts, condyloma)

6 Recurrent need for intravenous antibiotics to clear infections

7 Recurrent, deep abscesses of the skin or internal organs

8 Persistent thrush or fungal infections on the skin or elsewhere

9 Infection with normally harmless tuberculosis-like bacteria

10 A family history of primary immunodeficiency

These warning signs were developed by the Jeffrey Modell Foundation Medical Advisory Board. Consultation with Primary Immunodeficiency experts is strongly suggested. (C) 2016 Jeffrey Modell Foundation http://info4pi.org/library/educational-materials/10-warning-signs (Access date: 16 April 2020)

care of the patients exquisitely in their perspective but may not visualize the whole picture.

It is not easy to transfer medical information between different specialists and hospitals; therefore, we need to teach medical students how to keep medical records methodically and coordinate follow-up visits. The doctor should chronologically document each symptom presented by the patient, make a chart, and document each symptom in a timeline with presentations, tests, treatments, and responses to treatments. Giving a copy of these files to the patient would be beneficial in case the patient wants to seek help elsewhere.

Most of the clinicians do not feel competent at rare diseases. Furthermore, patients with rare diseases also think that their physicians have little knowledge about their diseases $(5,6,9)$. 
Table III: "MEDIC HAT PINE" Differential Diagnosis Mnemonic.

M Metabolic, micronutrients

E Endocrinological

D Degenerative, Drug-related

Inflammatory, Infective, post-infective, nowel diseases (e.g. SARS, MERS)

C Cancer, Congenital

H Haematological

A Autoimmune, Allergy

T Traumatic

P Psychological

I Idiopathic, latrogenic

N Neurological

E Environmental, Endemic diseases

In a recent survey on pediatricians, who are the most common group of physicians encountering rare diseases, 93\% of them had at least one patient with a rare disease recently; moreover, only $40 \%$ of them stated that they received comprehensive training on this subject (4). Almost all pediatricians (98\%) faced at least one difficulty while looking after children with rare diseases, namely lack of diagnostic tests, current treatments, clinical guidelines, and incapable of providing support for patients and their parents (10).

Establish a curriculum on rare diseases is incredibly challenging. We should set standard learning goals and prepare a blueprint for a vast majority of diseases with different complaints and symptoms. Therefore, we suggest that it would be more beneficial to use diverse methods together while approaching a patient with the initial diagnosis of a rare disease. The algorithm we propose provides a rapid and stepwise approach to a possible diagnosis together with long term management principles; nevertheless, there is rarely a single acceptable recipe for any patient, and not all diagnoses can fit precisely into an algorithm (Figure 1).

Physicians should consider alternative diagnoses whenever common illnesses cannot explain symptoms or adequately respond to the standard treatment regimes. Since rare diseases are $80 \%$ genetic, and $50 \%$ are seen in children, investigating genetic causes and immunodeficiencies should be the initial steps of the algorithm $(11,12)$. According to the patients' age, we can screen immunodeficiencies with ten questions (Table I-II) (11). The second step is looking for alert signs related to genetic diseases by asking six questions. These are called genetic red flags and easy to remember by using "Family GENES" mnemonic (12). Although most of the primary immunodeficiencies are inheritable, screening by genetic red flags is usually not enough to catch them. Physicians should prepare a multi-generation pedigree by taking a detailed family history (Family); also look for groups of congenital anomalies
(G) and extreme presentations of common diseases (E). Neurodevelopmental or neurologic symptoms (N), exceptional pathologic findings (E), and surprising laboratory values (S) are the other alert signs of genetic diseases.

If the patient does not fit any common diseases or show any signs of immunodeficiency and genetic disorders, thinking in a broader perspective and using the facility of another mnemonic (MEDIC HAT PINE) may be helpful (Table III). As far as we know, this reminder is anonymous and has minor variations between students. On the other hand, thinking of a doctor with a hat made of pine is a very sticky image and covers most other possible diagnoses of rare diseases like rare psychological disorders or cancers.

We want to pay particular attention to patients with similar symptoms from the same region. It is critical to prevent infectious diseases such as Severe Acute Respiratory Syndrome (SARS), Middle East Respiratory Syndrome (MERS), Coronavirus Disease 2019 (COVID-19), and toxications or endemic diseases. If a novel virus, like COVID-19, can be diagnosed early enough and confined in its origin, it may be named a rare disease; on the other hand, if it fails to be duly recognized, it may lead to a pandemic.

The literature search, finding national/international partnerships, and addressing families to psychosocial and peer support are the main components of holistic care. Online resources like Orphanet, Online Mendelian Inheritance in Man (OMIM), The European Organisation for Rare Diseases (EURORDIS), and the National Institute of Health $(\mathrm{NIH})$ are usually more useful than textbooks in case of rare diseases. Organizations providing information and support to families may differ according to country; therefore, clinicians should be familiar with the local services.

We suggest that handling rare diseases should be introduced in the latter part of the medical school curriculum, once enough patient-doctor relationship is experienced, rather than at the beginning of medical training when it is not easy to see the clinical relevance. Post-graduate educations in pediatrics and family medicine by using case-based scenarios in small groups may prepare clinicians when to suspect prospective patients, how to evaluate and search for possible diagnoses, record keeping, referring to relevant specialists, giving support to patients and families, and at the end establishing a healthy patient-doctor relationship. For both pre-graduate and postgraduate education, our algorithm may help the clinician to manage the patient thoroughly.

The algorithm we proposed has not been validated yet by testing with the students or compared to alternative approaches, including current practices. Further studies are needed in this direction.

In conclusion, by acquiring a holistic approach and using a comprehensive algorithm, clinicians may feel more confident 
and prevent additional problems and improve patients' quality of life with rare diseases.

\section{REFERENCES}

1. Richter T, Nestler-Parr S, Babela R, Khan ZM, Tesoro T, Molsen E, et al. Rare Disease Terminology and Definitions-A Systematic Global Review: Report of the ISPOR Rare Disease Special Interest Group. Value Health 2015;18:906-14.

2. Nguengang Wakap S, Lambert DM, Olry A, Rodwell C, Gueydan C, Lanneau V, et al. Estimating cumulative point prevalence of rare diseases: analysis of the Orphanet database. Eur J Hum Genet 2020;28:165-73.

3. Engel PA, Bagal S, Broback M, Boice N. Physician and patient perceptions regarding physician training in rare diseases: the need for stronger educational initiatives for physicians. J Rare Dis 2015;1:1-15.

4. Wolyniak MJ, Bemis LT, Prunuske AJ. Improving medical students' knowledge of genetic disease: a review of current and emerging pedagogical practices. Adv Med Educ Pract 2015;6:597-607.
5. Anderson M, Elliott EJ, Zurynski YA. Australian families living with rare disease: experiences of diagnosis, health services use and needs for psychosocial support. Orphanet J Rare Dis 2013;8:22.

6. Zurynski Y, Deverell M, Dalkeith T, Johnson S, Christodoulou J, Leonard $\mathrm{H}$, et al. Australian children living with rare diseases: experiences of diagnosis and perceived consequences of diagnostic delays. Orphanet J Rare Dis 2017;12:68.

7. Zurynski YA, Elliott EJ. Challenges of transition to adult health services for patients with rare diseases. Med J Aust 2013;198:5756.

8. Elliott E, Zurynski Y. Rare diseases are a 'common' problem for clinicians. Aust Fam Physician 2015;44:630-3.

9. Baynam G, Pachter N, McKenzie F, Townshend S, Slee J, KiralyBorri $\mathrm{C}$, et al. The rare and undiagnosed diseases diagnostic service - application of massively parallel sequencing in a statewide clinical service. Orphanet J Rare Dis 2016;11:77.

10. ZurynskiY, Gonzalez A, Deverell M, Phu A, Leonard H, Christodoulou $J$, et al. Rare disease: a national survey of paediatricians' experiences and needs. BMJ Paediatr Open 2017;1:e000172.

11. Foundation JM. 10 warning signs of primary immunodeficiency [Available from: http://info4pi.org/library/educational-materials/10warning-signs

12. Whelan AJ, Ball S, Best L, Best RG, Echiverri SC, Ganschow P, et al. Genetic red flags: clues to thinking genetically in primary care practice. Prim Care 2004;31:497-508. 